outbreak (Crawley Down) after referring to the Health Department file on virus diseases. The result of laboratory investigations is awaited.-We are, etc.,

$$
\begin{aligned}
& \text { C. R. Palmer. } \\
& \text { D. M. Richardson. }
\end{aligned}
$$

Haywards Heath, Sussex.

\title{
Blood Donation
}

SIR,- - On the morning of November 5 the B.B.C. broadcast an interview with a man who had given 100 pints (57 litres) of blood to the Transfusion Service. This gave me to think how generous these volunteers are, and an idea occurred to me that we could help ourselves much more than we do in this way. Everyone who has to undergo surgery except of a minor nature could donate a pint (570 $\mathrm{ml}$.) of their own blood before their operation in case they should need it. If not needed then the blood could go into the blood bank. Where major operative procedures were contemplated would it not be almost obligatory unless otherwise contraindicated ?-I am, etc.,

Wrexham, Denbighshire.

$$
\text { E. A. R. Evans. }
$$

\section{Present State of Medicine}

SIR,- - It seems obvious that the unanimous dissatisfaction of the G.P. is concerned with his whole existence in the present set-up in the N.H.S., and that a change must be radical. As this dissatisfaction is not apparent in the case of the consultants' service-consultants seem well satisfied with their terms-then surely we must aim at this well-tried and successful method of service and remuneration.

General practitioners must have their surgeries in hospitals. The out-patients are not used all day. and could accommodate several doctors at a time. All the ancillary help is there. We may keep our own patients as the consultants have theirs, and could do sessions in accordance with our numbers, and if we wished have private sessions at home. Visits could be made to our patients too sick to attend, and we should be paid for each visit. Subsequent visits for dressings and injections could be made by the district nurse or other qualified person. If patients on our list wish to see us privately, they may do so in the same way as patients may see a consultant. By working in a hospital community our postgraduate education would be a continuous process. Holidays and free week-ends could easily be arranged amongst our colleagues. If consultants can be provided with these facilities free, there can be no excuse for refusing them to the G.P.

Not until we are given these advantages will the standard and dignity of general practice under modern conditions of knowledge and investigation be fulfilled. -I am. etc.

Prestwich, Manchester.

N. LAUNER.

\section{Doctors' Pay}

Sir,--In your leading article of November 30 (p. 1349) you say, "General practitioners, we may be sure. will want to be in close touch with their colleagues in consultant and hospital service and approach the Review Body as a united profession."

I would be very interested indeed to know whether this is in fact the feeling of most of my colleagues in general practice. The present urgent problems are entirely our own, and involving the consultants in them merely slows down the already ponderous progress being made. May I ask the Association to get on with the job of improving our lot? Many of us will remember being sold down the river in 1948 by the consultant's colleges, we would rather that they were not involved in the present crisis, particularly bearing in mind the fact that their method of remuneration has no connexion whatever with ours.-I am, etc.,

\section{E. J. Allaway.}

Birmingham 17.

\section{College of Psychiatry}

SIR,-Reports in the medical press have engendered the belief that the R.M.P.A. has made a firm decision to proceed towards the formation of a College of Psychiatry. This is not so. The recent meeting in London was held in order to stimulate discussion and thought about the whole problem. not to arrive at a binding decision. Such a decision can only be reached after a postal hallot of the whole membership of the R.M.P.A. The next step will be to discuss whether the time is vet ripe to hold such a ballot. -I am, etc.,

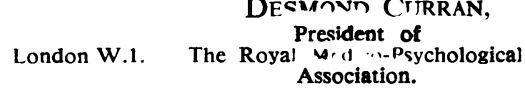

\section{Gall-bladder Dyspepsia}

SIR,-Dr. E. W. Sheaf's approach to dyspepsia (October 26, p. 1065) is still impregnated with the Morgagnian concept of seats and causes of maladies studied anatomically (1761). What needs to be remembered, however, is that the vagus nerve supplies many structures besides the digestive tract, and that irritation of any branch of it can be responsible for dyspepsia. Thus examination and investigation of the areas of its distribution is needed in all cases of dyspepsia and not merely of the gall-bladder in cases supposedly of that origin. It is no accident that the so-called gall-bladder picture is being questioned. The reign of pure anatomy is over; physiology reigns in its stead. and classifications like toxic. obstructive, irritative, etc., are scholastic after-thoughts, good for teaching and examinations but not for the stuff of practice.-I am, etc.,

Capetown, South Africa.

\section{Collapse after Pethidine and Promazine}

SIR,-Collapse of the obstetric patient following intravenous administration of pethidine and promazine has been described by Mr. A. G. Amias and Mr. D. Fairbairn (August 17, p. 432) and Mr. D. J. P. O'Meara (September 21, p. 749). Collapse after intramuscular injection is illustrated by the following case.

A primigravida, aged 17, was booked at St. Paul's Hospital, Hemel Hempstead; he expected date of delivery was March 3, 1962. The pregnancy was normal. At 39 weeks her blood-pressure was $140 / 90$. She was admitted at term with a blood-pressure of $150 / 70$. Pethidine $100 \mathrm{mg}$. with promazine $50 \mathrm{mg}$. was given intramuscularly prior to vaginal examination. Shortly afterwards she collapsed and became cyanosed; the limbs were spastic and the pulse imperceptible. Cardiac arrest did not occur. Oxygen was administered, and coramine $2.5 \mathrm{ml}$. and aminophylline $10 \mathrm{ml}$. were given intravenously. She was tilted head down and then she slowly recovered.

She went into spontaneous weak labour three days later. Artificial rupture of the membranes was performed after a further three days. Spontaneous normal delivery occurred. Discussion with the patient during the puerperium elicited no information about sensitivity to drugs nor to other substances.

During her second pregnancy she remained well until term, then the blood-pressure rose to $145 / 90$. A week later the blood-pressure was $150 / 90$, with slight albuminuria. Two days later the blood-pressure was 125/80; the albuminuria persisted. She went into spontaneous labour at the 42 nd week and delivered normally, on May 25, 1963, a bahy boy weighing $7 \mathrm{lb} .2 \mathrm{oz}$. $(3.2 \mathrm{~kg}$.). We did not have the pharmacological courage to repeat the pethidine and promazine.

Observers agree that intramuscular pethidine and promazine usually give the desired effects safely. The intravenous route can sometimes give dramatic and alarming results for many drugs. Dr. D. Waghmarae (October 12, p. 936) describes maternal collapse following intramuscular pethidine $(100 \mathrm{mg}$.) with levallorfan (1.25 mg.) and promethazine hydrochloride $(25 \mathrm{mg}$.). I have seen collapse of the non-pregnant female following intramuscular promazine given post-operatively.

Pharmacological research will presumably, in due course, give the answer and solve the problem; at present it remains as baffling and alarming as untoward reactions to aspirin, which may occur on first encountering the chemical. The practical obstetrical lesson from the recorded cases is that expectancy yields better foetal dividends than radical intervention.-I am, etc.,

London W.1.

Ian A. Donaldson.

\section{Schistosomiasis in the West Indies}

Sir,-During the discussion at the clinicopathological conference reported in the B.M.J. of November 30 (p. 1392) 
Dr. J. P. D. Mounsey said, “It was very interesting to see schistosomiasis in the liver and I did add that in the past he had had a fever; but who hasn't, among people coming from the West Indies and elsewhere?"

As this might be taken to mean that schistosomiasis is common in the West Indies it might be worth recording that it was far from common some 15 years ago. There was a small endemic focus in only one of the Windward and Leeward islands in the little town of Soufrière in the island of St. Lucia, where about 3\% of the inhabitants showed a mild infestation with ova of both Mansoni and Haematobium. The rest of the island was free, as were the other islands of the group.

British Guiana, on the South American mainland, is a land of many waters and canals which would appear to constitute a congenial home for the vector, but schistosomiasis is unknown there also, though very common in the adjoining Dutch territory of Surinam.

I have never found an explanation for this curious selective distribution of the parasite, but it is very interesting. $-\mathrm{I}$ am, etc.,

Iersey, C.I.

\section{P. A. Clearkin.}

\section{Mental Retardation}

SIR,-Dr. J. Gibson's letter (November 9, p. 1201) is a constructive step towards a revised terminology in this branch of medicine, particularly in relation to the Mental Health Act (1959). Ample support for Dr. Gibson's main suggestions is demonstrated by the letters appearing subsequently (November 30, p. 1405).

The Mental Health (Scotland) Act, 1960 , retains the term mental deficiency and does not incorporate the terms subnormal and severely subnormal. This terminology works in practice. Vagueness and confusion have been avoided by retaining a term which everyone understands and which has not been too heavily stigmatized. Arising from Dr. Gibson's letter is the point that legally subnormality and psychopathic disorder are linked with certain age limits. I suggest that this is an opportune time not only to revise the terminology but also the concept of rigid age limits for specific types of mental disorder, as these have no meaning in medical practice.I am, etc.,

Strathmartine Hospital

M. E. York-Moore

Dundee.

\section{Tranylcypromine and Cheese}

SIR,--In view of the increasing number of reports of alarming reactions following the eating of cheese in patients who are taking tranylcypromine, it was thought that the following case report would be of interest.

A female patient aged 46 years was taking "parstelin" tablets, one twice a day. At

5.30 p.m. one evening she consumed a meal of cheese on toast, and a tablet of parstelin was taken at the same time. At 6 p.m. she began to feel unwell, developed a severe occipital headache which spread to the frontal region. She was nauseated and vomited. Shortly after this she noticed that objects in her field of vision became very small and seemed to be a long distance away. This quite suddenly gave way to complete blindness, which was present when she was first seen at 7.30 p.m. No opportunity presented itself for a blood-pressure recording, for almost immediately after my arrival she went into a generalized epileptiform convulsion. This lasted three minutes and was treated with intramuscular soluble phenobarbitone gr. 3 (0.2 g.). Her blood-pressure subsequent to the fit was $140 / 90$. The patient was removed to the hospital as an emergency, where she was given paraldehyde during the night. When she awakened from the effects of her anticonvulsants the next day she was completely recovered. had no headache, and her eyesight was normal.

One week later she remained well and had no symptoms.

-I am, etc.,

Gravesend, Kent.

\section{Ronald B. Miller.}

\section{"Thylin"}

SIR, - We should like to correct errors made in connexion with our product "thylin" made in "To-day's Drugs" in the Journal of November 23 (p. 1317). The spelling is incorrectly given as "thyllin" and it is also stated to be a derivative of phenylbutazone. This is not so. Phenylbutazone is a pyrazolidine derivative, whereas thylin is a pyrazol derivative. This confusion may give a false impression, because phenylbutazone is known to produce toxic effects, such as peptic ulceration, oedema, and agranulocytosis.

In six years' use thylin has not been reported to produce any such toxic effects. Indeed. those doing the clinical trials have stressed not only its antirheumatic effects but also its freedom from side-effects. Surely no controlled

\section{POINTS FROM LETTERS}

\section{Nomenclature of Drugs}

Dr. Roderick R. Hamilton (Hawick, Roxburghshire) writes: I fail to understand what instructions Dr. C. H. D. Bartley (November 30, p. 1406) is attempting to follow as he strives always to prescribe B.P. preparations as opposed to the ethical product, for surely no instructions as such exist. While aiming to educate and guide the doctor, the State propaganda on the subject of prescribing, in spite of intimidating undertones, at no time constitutes instructions, and the doctor remains entirely free to prescribe whatever he considers necessary for his patients.

Like your correspondent, I too am baffled by the modern nomenclature of drugs ; having witnessed the abandonment of Latin names in the interests of clarity, we are now confronted with names like tranylcypromine and chlordiazepoxide hydrochloride, which are virtually devoid of meaning. No wonder character. trials are needed, as suggested in "Today's Drugs," to demonstrate the safety of a drug if a large enough number of patients have received it. It is estimated that over half a million patients have received 2:3-dimethyl-4-nicotinamido-1phenyl-pyrazol-5-one since 1957 without any serious side-effects being reported. This should be sufficient evidence to show its freedom from side-effects.-I am, etc.,

West Pharmaceutical Co. Ltd.,
Hove 3, Sussex

K. J. KNIGHT.

\section{Round the Fountain}

SIR,-Dr. L. W. Batten (December 7 p. 1469) having broken the ice, I would like to suggest that Professor D. V. Hubble, in his review of my book We Met at Bart's (November 23, p. 1333), has confused history with histrionics. He dwells almost exclusively on the cynical, sometimes cruelly witty, aspect of Drysdale's character, and refers to him as representing " the least good aspect of the Bart's tradition."

As Dr. Batten makes clear, Drysdale was pre-eminent as a teacher during the whole of his time at Bart's, and it was to repay this debt in a very minor degree, a debt incurred by me personally over ten years, that I made him the central character of my attempt at a period piece. Having embarked on this portrait of a great man, it was only just to refer to foibles, weaknesses, and defects in his

Drysdale's influence upon the Bart's tradition can be measured by the quality of the majority of students whom he attracted. It was then possible to choose one's firm; and Adrian, J. Trevan, I. de Burgh Daly, Basil Verney, C. H. Andrewes, I. L. Braun, Lindsey Batten himself, and countless others shared a determination to serve under the finest teacher of his generation.-I am, etc.,

London W.1. GEOFFREY BOURNE.

such nonsense syllables so readily lose their place in the therapeutic memory store, to the more simple, euphonic, and easily remembered trade names.

Sutureless Skin Closure

Dr. T. W. Froggatt (St. Alfege's Hospital, London S.E.10) writes: For over 40 years I have used, and taught the use of, long strips of adhesive strapping for the closure of wounds instead of stitches. They are painless in application and can be used by the comparatively unskilled without prejudice to later treatment. They are effective and unlikely to introduce infection or to cause complications in the event of infection occurring. The strips should be 3 or $4 \mathrm{~mm}$. ( $1 / 8$ or $1 / 6$ in.) wide and about $10 \mathrm{~cm}$. (4 in.) long, so that a firm grip on the skin may be formed beyond the area of dampness. One side should be applied first, the wound then drawn together and the other side stuck down in moderate tension. 